\title{
HOW DOES THE CIRCULATION OF WORKS OF ART AND EXHIBITIONS FUEL ACCULTURATION?
}

HARUMI KINOSHITA

\section{ABSTRACT/ABSTRAKT:}

A museum should be considered not only a local anchorage but also a place that is integrated into the logic of the flow. Thus, the study of the circulation of works of art and exhibitions is crucial from a museology standpoint. This paper shows the effects of the movement of works of art and exhibitions in the cultural field. The analysis of these effects determines the taste of the public, the construction of a museum's reputation, and the phenomenon of acculturation. By focusing on the process of acculturation in Japan through French museums, this paper argues that the circulation of works of art and exhibitions is one strategy for cultural diffusion.

\section{Jak přispívají zápůijčky uměleckých děl a výstav $\mathrm{k}$ akulturaci?}

Muzea by měla být považována nejen za lokální kulturní centra, ale i za místa integrovaná do logiky kulturního pohybu. Studie věnovaná zápůjčkám uměleckých děl a výstav má tedy $\mathrm{z}$ hlediska muzeologie zásadní význam. Článek představuje účinky pohybu uměleckých děl a výstav $v$ oblasti kultury. Analýza těchto účinků určuje vkus diváka, přispívá k budování pověsti muzea a fenoménu akulturace. Studie se soustředí na proces akulturace v Japonsku prostřednictvím muzeí ve Francii a ukazuje, že zápůjčky uměleckých děl a výstav jsou jednou ze strategií kulturní difúze.

\section{KEYWORDS/KLÍČOVÁ SLOVA:}

acculturation - appropriation circulation - diffusion - turnkey exhibition

akulturace - apropriace - zápůjčky difúze - „výstava na klíč”

\section{Introduction}

A strategy for cultural diffusion by the circulation of works of art and exhibitions has experienced strong development over the last ten years at museums. Museology, which takes a keen interest in various aspects of the museum world, has overlooked that the circulation of works of art and exhibitions is part of museums. In fact, such circulation is not just a technical issue that emerges at the artwork management level; it is a social phenomenon that is intensifying and raising questions about the development of a museum's activities. Analyzing the circulation of the works of art and exhibitions lets us determine symbolic operations in the dimension of social impact at a museum: what are the effects of the movement of works of art and exhibitions? What are the strategies for their circulation?

When considering the circulation of works of art related to temporary exhibitions, we should discuss the question of cultural diffusion on an international scale. This paper focuses on the circulation of works of art and exhibitions, especially at French museums such as the Louvre Museum, the D’Orsay
https://doi.org/10.5817/MuB2017-2-3

Museum and MNAM-CCI (Musée National d'Art Moderne-Centre de Création Industrielle/the Georges Pompidou Center), and describes the process of acculturation in Japan. If the circulation of works of art and exhibitions is an instrument of acculturation, this acculturation phenomenon can be identified, particularly in Japan, a country that often hosts turnkey exhibitions organized by worldwide museums.

Chapter 1 introduces the history of the circulation of works of art and exhibitions, especially by French museums in Japan. Chapter 2 explains the notion of circulation from a communicational point of view by referring to that of Raffestin (1980), Latour (1996), and Jeanneret (2008). Chapter 3 describes the diffusion strategy of French museums, which lends its collections around the world, and effects of such loans. This work shows the strategy of cultural diffusion at museums by the phenomenon of acculturation.

\section{Historical approach}

Historical research, which is necessary to understand the circulation of works of art and exhibitions, allows us to comprehend the origins, determine the purposes, and recognize the acceleration of this movement. Chapter 1 treats cultural diffusion from the 1920s until the 1990s. 


\subsection{Initial circulation of works of art and exhibitions by French museums in Japan}

I show first the beginning of the circulation of works of art and exhibitions by French museums in Japan to explain that the cultural diffusion between the two countries has been remarkable already in the 1920s and that the process of acculturation or appropriation has already been seen.

\section{The exhibition of Contemporary} Art in Japan was held in 1922 until 1931. The 8th exhibition held in 1929 presented about 250 works of art from such artists as Boudin, Fantin-Latour, Pissarro, Rodin, Van Dongen and Zadkine. Houshin Kuroda, ${ }^{1}$ one of the organizers of this exhibition, argued that the cultural exchange between French and Japan through the exhibitions fueled a mutual understanding between both countries. ${ }^{2}$ In the same year, Paris hosted a Japanese art exhibition, as early example of reciprocal intercultural knowledge.

In 1951, the following exhibition was shown in Tokyo: Exposition d'art français contemporain; œuvres présentées à Pairs au Salon de Mai 1950. About 60 works of art were presented from such artists as Coutaud, Dufresne, Hartung, Labisse, Schneider and Soulages. Teiichi Hijikata ${ }^{3}$ wrote that this exhibition offered insights into what the new French generation is thinking. ${ }^{4}$ Art magazines featured this exhibition, and artists and art critics discussed French artists and artistic movements in France. Many Japanese felt great interest in this exhibition.

\footnotetext{
1 Houshin Kuroda (1885-1967) was an art critic.

2 Cat.Expo. Exposition d'art Français

contemporain. Tokyo: Nichifutsu Geijutsusha,

1929, p. 3.

3 Teiichi Hijikata (1904-1980) was an art historian and art critic.

4 Cat.Expo. Exposition d'art français contemporain; œuvres présentées à Paris au Salon de Mai 1950.

Tokyo: Mainichi Shimbun, 1951, p. 4.
}

In 1954, the Asahi newspaper company sponsored in Tokyo, Kyoto and Fukuoka an exhibition entitled a French Art Exhibition in Japan, which displayed about 360 works of art from the early medieval period to the mid-19th century from such artists as Poussin, Le Brun, Boucher, Fragonard, Chardin, Ingres, Gericault, Delacroix, Chasseriau, Courbet and Renoir. Note the France and Japan had just reached a cultural agreement in 1953. Even though this exhibition's realization was due to this cultural agreement, nevertheless, it was not easy to send to Japan more than three hundred works of art from the number of different French museums. Prime Minister Shigeru Yoshida $^{5}$ declared that the French culture is admired by the cultured people of the world, including the Japanese, and believed that this exhibition greatly contributed to the development of the Japanese culture. ${ }^{6}$

In 1961 in Tokyo, an exhibition called French Art Exhibition $1840-1940^{7}$ presented art from the mid-19th century through World War II, including works by Millet, Manet, Degas, Cezanne, Van Gogh, Seurat, Daumier, Redon, Lautrec, Bonnard, Modigiliani, and Soutine. This exhibition set a record for visitors: 1477388 over a period of 119 days. It offered not only a collection from the number of French museums but also a display method. In an interview with the Asahi newspaper company, Bernard Dorival ${ }^{8}$ said that he was touched by the positive attitudes of the Japanese visitors whom he

\footnotetext{
5 Shigeru Yoshida (1878-1967) was former Prime Minister of Japan from 1946 to 1947 and from 1948 to 1954.

6 Cat.Expo. Exposition d'art Français au Japon. Tokyo: Asahi Shimbun, 1954, p. 4.

7 This exhibition was also shown in Kyoto in 1962.

8 Bernard Dorival (1914-2003) was a French art historian and art critic. He was named the assistant curator of the National Museum of Modern Art in 1941. He was the Commissioner-General for this exhibition.
}

described as thirsty for French art. He remarked that many young people saw this exhibition and bought many catalogues. In addition to Japanese contemporary art, he argued that Japanese art had an international aesthetic. In other words, it provided a Japanese flavor instead of just importing a western style, and he believed that Japanese art successfully united Japanese traditional sensitivity with European contemporary art. ${ }^{9}$

\subsection{A symbolic event: lending the Venus of Milo to Japan for the 1964 Olympic Games}

The lending to Japan in 1964 of the Venus of Milo, which was authorized by André Malraux, is emblematic because it shows how temporary exhibitions can function as an instrument to satisfy social demands and to promote acculturation.

The Venus of Milo was shipped to Japan in 1964 and exhibited at the National Museum of Western Art in Tokyo and at the Kyoto Municipal Museum of Art. The Japanese government sought to display the Venus of Milo as well as the Olympic Games because both symbolized Japan's admission into the realm of developed countries. To achieve this goal, the Asahi newspaper company took a cultural, diplomatic, and economic initiative.

Takio Ena, the department head of the Asahi newspaper company's cultural project, sent a letter on May 23, 1963 to Bernard Dorival: "Following the great achievement of French - Japanese cultural exchange program in the two French Art Exhibitions in Japan, and it concert with the coming big sports event of the Tokyo Olympic Game in 1964, Asahi Shimbun again plans a unique

9 Interview with Mr. Bernard Dorival, in Asahi Shimbun, 1961, December 4. 
and quite an ambitious project, dynamic enough to cope with the great international sports event both in its impact on public psychology and in its cultural significance - an exhibition of a single but the supreme treasure of France, VENUS OF MILO."10

On February 12, an agreement was concluded between the Japanese and French governments for lending the statue to Japan. Its presentation in Tokyo and Kyoto was a great success. It set a new attendance record for an art exhibition in Japan: over 1.7 million visitors over a 74-day period compared to almost 1.5 million visitors to an exhibition entitled French Art 1840-1940 in 1961 over 119 days.

The economic effect was reported another huge success. The sale of catalogues reached 431583 copies. And the souvenirs sold over 180 million yen. Japan paid to France ten percent royalty on total sales. ${ }^{11}$ To thank this success, Takio Ena, the department head of the Asahi newspaper company's cultural project, sent a report on June 2, 1964 to Jacques Jaujard, the Sectretary-General of Cultural Affairs: "We of the Asahi Shimbun are unanimously delighted at the fabulous success of this exhibition and happy with the fact that we could return the Statue safely without any mishap to the Statue. We would like to take this opportunity to express our sincere thanks and appreciation to Minister Malraux and you for your coordinated high considerations extended to us for this great cultural project. We would like to express our gratitude to Mr. Landais, $M r$, Qunium and all of the 9 people of Louvre Museum who kindly cooperated with us all the time and impressed on the Japanese

10 Archives des musées nationaux, 4CC49.

11 Documentation AGER, Ma0399. directly related to this exhibition with goodwill and friendliness. We believe we should not ignore the significant fact that this cultural project contributed a great deal to the betterment of the friendly relations between the two countries through these direct people-to-people contacts." 12

1.3 Operation of turnkey exhibitions in the 1990s and the start of the Pompidou Center's Hors les murs

Collections that are distributed outside of museums are considered loans. Lending of works of art for the exhibitions should not produce profit. ${ }^{13}$ However, when the lending is remunerated as part of an exhibition from a collection, such a situation is called a turnkey exhibition which allows museums to crate benefits by circulating their collection. An exhibition entitled Des collections royales au Grand Louvre ${ }^{14}$ brought the Louvre Museum 10 million French francs, ${ }^{15}$ and when the Barnes Foundation organized an its turnkey exhibition called Great French Paintings from the Barnes Foundation in Paris and in Tokyo, ${ }^{16}$ this foundation received about 7 million an exhibition from Paris and between 4 million and 5 million from Tokyo as loan fees. ${ }^{17}$

The operation of turnkey exhibitions was remarkable in the 1990s. Asian countries, especially

\section{Ibidem}

13 Décret n81-240 du 3 mars 1981 relatif aux prêts et aux dépôts d'œuvres des musées nationaux, JO, 13 mars 1981. In CHATELAIN, Jean. Droit et administration des musées. Paris: La Documentation française, 1993, p. 434.

14 This exhibition circulated in 1993 in Japan; in Yokohama (Yokohama Museum of Art) and in Kobe (Kobe City Museum).

15 SPAAK, Isabelle. L'essor du clé en main. Le Journal des Arts, mars 1997, no. 34

16 This exhibition was shown at the D'Orsay Museum between 1993 and 1994, and at the National Museum of Western Art (Tokyo) in 1994.

17 PALMER, Norman. Art Loans. London: Kluwer Law International and International Bar Association, 1997, p. 40.
Japan, often welcomed them. To name a few of these turnkey exhibitions, Japanese museums hosted collections from the Louvre Museum in 1991, 1993 and 1997, the D'Orsay Museum in 1995 and 1999, the Barnes Foundation in 1994, the Tate Gallery in 1998, and the National Gallery of Washington in 1999.

In 1997, a new program for exhibitions called the Hors les murs opened its doors. Such exhibitions, which were formulated by the Pompidou Center during its renovation to enhance the value of its collection, were designed by MNAM-CCI and presented outside of the Pompidou Center. Hors les murs program of exhibitions developed a partnership between MNAM-CCI and foreign cultural institutions and allows major works of art to be rent to reach larger audiences.

During the period 1997-1999, seventeen Hors les murs exhibitions were realized and thirteen countries hosted them.

Japan became the first foreign country to benefit from the Hors les murs exhibition program. An exhibition entitled a Collection from the Pompidou Center: Masterpieces of MNAM was shown in Tokyo and attracted over 300000 visitors. ${ }^{18}$ Another exhibition called the Photographers of Paris was presented in both Tokyo and Osaka. In Italy, the exhibition of Kandinsky was shown in Milano. ${ }^{19}$ An exhibition entitled Figures de peintres was presented in Bogota and in Mexico. ${ }^{20}$

The year 1998 was characterized by the relationship with the United States; an exhibition called

\footnotetext{
18 Rapport d'activité du Centre Pompidou 1997, p. 59.

19 Ibidem, p. 66.

20 Ibidem.
} 
Rendezvous. Masterpieces from Centre Georges Pompidou and the Guggenheim Museum was shown in New York and another exhibition entitled Premises: Invested Spaces in Visual Arts, Architecture and Design from France, 1958-1998 was presented in also New York.

In 1999, an exhibition called Les Années Supports/Surfaces dans les collections du Centre Georges Pompidou, Musée national d'art moderne circulated in the world; this exhibition was presented in Madrid, Namur (Belgium), Lodz (Poland), Rome and in Pori (Finland).

What is specific to the Hors les murs program is that it validates the reputation of the Pompidou Center to wider audiences, especially those less familiar with Western art history and expands diffusion networks.

\section{Circulation and communication}

From a theoretical point of view, I am trying to comprehend the notion of circulation in the communication field. How does the circulation of works of art and exhibitions affect communication? From three points of views, I investigate the circulation of information related to the manifestation of power and how it builds a new system that allows confrontation (Latour) and reappropriations (Jeanneret).

\subsection{Circulation as a spectacle of power}

Claude Raffestin proposes a circulation-communication combination: "Circulation and communication are two sides of mobility.... We discuss circulation every time we transfer men and goods lato sensu, while we reserve the term communication to the transfer of information.
Even so, this distinction, where everything may be useful, can appear ambiguous because it might help us accept whether circulation or communication is appropriate. In reality circulation and communication, simultaneously exist in all 'transportation'. The men or the goods that circulate are the carriers of information, and therefore they 'communicate' something. Similarly, information that is communicated is simultaneously a 'good' that 'circulates'." 21

Circulation and communication can be distinguished; circulation transfers men and goods, and communication transfers information. However, such circulation and communication as men or goods that circulate depart from information. Communicated information is a good that circulates.

Presupposing that the notion of circulation is more general than communication because the first gathers everything that is mobilizable, Raffestin argues that circulation is a spectacle of power that extends the theory of Stroudzé. Circulation is a spectacle of power because it is visible by the flow of men/women and the mobilized goods by the infrastructure that it assumes. ${ }^{22}$ In this context, power cannot be hidden or controlled, as Raffestin emphasizes: "Circulation itself as spectacle should be made, we cannot conceal it, hide it, in short, it is futile to make it invisible. Consequently, we have to exalt it, show it, and exhibit it to the light of day. Thus, we can know all or almost all about the networks of circulation.... The function of the mobility of power is not finally as well known as the material of circulation and is known well as communication: the popularization

\footnotetext{
21 RAFFESTIN, Claude. Pour une géographie du pouvoir. Paris: Librairies Techniques, 1980, p. 181 English translation by author. 22 Ibidem, pp.182-183.
}

of the circulation of networks, the privatization of communication networks." ${ }^{23}$

Circulation, which is a spectacle because it cannot be masked, allows us to see its networks; but communication can conceal itself.

Furthermore, Raffestin's notion of circulation, such as the spectacle of power, can contribute to our subject; the circulation of works of art and exhibitions make visible all of the effects on such mobile museums. The movement of works of art and exhibitions drapes museums with a positive reputation.

\subsection{Circulation of information: Bruno Latour's metaphor}

Bruno Latour poses a question about circulation through the institution of libraries and emphasizes the mechanism of registration that he calls a "center of calculation". ${ }^{24} \mathrm{~A}$ library is not an isolated place or a haughty place. Latour considers it the "node of a large network where neither signs nor materials circulate, but instead the materials become the signs". ${ }^{25}$

Using the example of the drawings of naturalist, Pierre Sonnerat, who displayed his self-portrait during a journey to Papua New Guinea in 1776, Latour defined the information: "Information in not a sign, but a report established between two places; the first becomes a periphery, and the second becomes a center, provided that a vehicle circulates between the two that we often call a form, but I insist on

\footnotetext{
23 Ibidem, pp. 183-184. English translation by author.

24 LATOUR, Bruno. Ces réseaux que la raison ignore: laboratoires, bibliothèque, collections. In BARATIN, Marc and Christina JACOB (eds.). Le pouvoir des bibliothèques: La mémoire des livres en Occident. Paris: Albin Michel, 1996, p. 23. 25 Ibidem.
} 
its material aspect and call it an inscription." 26

Latour is pressing hard for this point: "information is not a 'form', in the Platonic sense of the word, but a very practical and material report between two places". ${ }^{27}$ According to Latour, information is not a sign, but a loading of registrations. ${ }^{28}$

Latour explains this process of registration using the example of collections in museums, especially the collection of the Natural History Museum ${ }^{29}$ whose Old Gallery gathered birds from around the world. Information about each bird is reported in the museum from other locations and established a comparison among the birds. The museum collections, like the library, become commensurable with all other information once the information registered. ${ }^{30}$

In this context, the library or a museum's collection is a center of the calculation where the information circulates through networks of transformation that connect each registration in the world and each registration of all those who are commensurable. ${ }^{31}$ Latour clarifies this mechanism of the center of calculation: "The networks of transformations send to the center of calculations, by a series of displacements - reduction and amplification - an increasing number of registrations. These registrations circulate in both directions, which is the only way to ensure the fidelity, the reliability, the truth between the represented and the representative." 32

\footnotetext{
26 Ibidem, p. 24. English translation by author.

27 Ibidem, p. 25.

28 Ibidem, p. 26.

29 Ibidem, p. 31.

30 Ibidem, pp. 31-32.

31 Ibidem, p. 36.

32 Ibidem, p. 38. English translation by author.
}

Networks that pass information reach the center of calculation, where information is registered. In the center of calculation, as soon as many pieces of information are registered, they become comparable.

In this mechanism of the center of calculation, the networks reach it by bringing information; the library becomes a laboratory: "A library is considered a laboratory that cannot remain isolated, as if it is accumulating, maniacally, scholarly, and in a cultivated fashion, signs by the millions. It serves as a shooting yard, as a bank, playing in the universe of networks and the center's role in Wall Street or the city for capitalism." ${ }^{33}$

Latour emphasizes that a library is not a simple isolated place at which papers are accumulated, but a center of calculation where information is registered: this registration allows information to circulate.

This notion of a center of calculation can be applied to museums. A museum is in a place where a work of art is registered, and once this registration is realized, the work of art and the exhibition, in the sense of the assemblage of works of art, have an opportunity to be circulated by networks. In this context, current museums no longer operate as a place for the preservation of works of art; they are destined to circulate works of art and exhibitions.

\subsection{Circulation and appropriation}

Yves Jeanneret promoted the concept of triviality, which also serves as a theory of circulation. He referred to the theory of Gabriel Tarde: "Anything that appears to

33 Ibidem, p. 39. English translation by author. constitute a group or an institution manifests a circulation of ideas in all the people's heads." ${ }^{34}$ Once ideas appear, spread, multiply, and disperse, they are not concentrated in a place but they circulate. Jeanneret explains how culture circulates: "Talking about triviality does not mean that we are especially interested in the banal, in the hackneyed, or even in the dregs. Rather we embrace the culture in a certain way since objects and representations do not remain closed in themselves, but they circulate and pass through the hands and the minds of people. This choice however is not absolutely neutral. It suggests that these objects enrich and change across social spheres. And even they become cultural by this creative circulation." 35

For Jeanneret, culture is comprised of objects and the representations that circulate in society through the people, and Tarde's theory is that "ideas appear and then spread, reproduce, and disseminate". ${ }^{36}$ Through that circulation, objects and representations become cultural.

By highlighting the trivial life of being cultured, Jeanneret argues that society manifests the circulation of ideas.

The notion of triviality defined by Jeanneret allows us to designate how ideas and culture circulate and permits us to recognize that the circulation of works of art and exhibitions in museums are social facts. This definition broaches the problem of the formation of taste. Public taste is influenced by the circulation of works of art and exhibitions which Francis Haskell shows through two exhibitions: Mostra della Pittura Italianna del Sei

34 JEANNERET, Yves. Penser la trivialité. Paris: Lavoisier, 2008, p. 28.

35 Ibidem, p. 14. English translation by author 36 Ibidem, p. 29. 


\begin{tabular}{|l|c|c|c|c|c|c|c|c|c|c|c|}
\hline & 2007 & 2008 & 2009 & 2010 & 2011 & 2012 & 2013 & 2014 & 2015 & 2016 & Total \\
\hline The Louvre Museum & 0 & 2 & 2 & 1 & 0 & 1 & 1 & 0 & 2 & 1 & 10 \\
\hline The D'Orsay Museum & 3 & 3 & 1 & 4 & 0 & 0 & 0 & 1 & 0 & 1 & 13 \\
\hline MNAM-CCI & 1 & 0 & 0 & 1 & 2 & 0 & 0 & 2 & 0 & 1 & 7 \\
\hline Total & 4 & 5 & 3 & 6 & 2 & 1 & 1 & 3 & 2 & 3 & 30 \\
\hline
\end{tabular}

Fig. 1: Lending in context of turnkey exhibitions to Japan from 2007 to 2016 organized by the Louvre Museum, the D’Orsay Museum and MNAM-CCI

e Settecento at the Pitti Palace in Florence in 1922 and Peintures de la réalité at the Orangerie Museum in Paris in 1934 and 1935. ${ }^{37}$ The Florence exhibition concentrated on such 18th century Italian painters as Caravaggio, and the Paris exhibition concentrated on such 17 th century artists as Georges de la Tour and Le Nain. Haskell argues that these exhibitions modified the public understanding of art evolution's through history: "What is remarkable about the Palazzo Pitti and Orangerie exhibitions is not only the way in which they did alter people's understanding - and, of course, the way in which they promoted a certain misunderstanding - of the Old Masters of Italy and France, but the impact that this had on contemporary art and on larger intellectual circles." 38

\section{Manifestation of French museums' turnkey exhibitions in the last decade}

In my last chapter, I analyze the circulation of works of art and exhibitions, especially at French museums. I chose three French museums (the Louvre Museum, the D'Orsay Museum and MNAMCCI) and focused on their turnkey exhibition programs to show how this exhibition mode influences the public's taste, the construction of a museum's reputation, and the phenomenon of acculturation.

37 HASKELL, Francis. The Ephemeral Museum: Old Master Paintings and the Rise of the Art Exhibition. New Haven, London: Yale University Press, 2000, pp. 128-142.

38 Ibidem, p. 142.

\subsection{Flow of turnkey exhibitions from 2007 to 2016}

Here I show statistics about three French museums that lent 30 turnkey exhibitions to Japan from 2007 to 2016 (Fig. 1).

The Louvre Museum lent ten turnkey exhibitions during this period, the D'Orsay Museum lent thirteen, and MNAM-CCI lent seven during the same period. Breaking down the number per year, four turnkey exhibitions were lent in 2007, five in 2008, three in 2009, six in 2010, two in 2011, one in both 2012 and in 2013, three in 2014, two in 2015, and three turnkey exhibitions in 2016.

The year 2010 witnessed a remarkable movement of turnkey exhibitions. The amount for this year reflects four lendings from the D'Orsay Museum: an exhibition entitled Post-impressionnisme, chefsd'œuvre du musée d'Orsay ${ }^{39}$ was shown at the National Art Center in Tokyo, an exhibition called Art Nouveau et industrie du luxe en France circulated in the Nagasaki Prefectural Art Museum, the Hiroshima Prefectural Art Museum, and the Setagaya Art Museum in Tokyo, an exhibition entitled Manet et le Paris moderne was presented at the Mitsubishi Ichigokan Museum in Tokyo and a Degas exhibition was held at the Yokohama Museum of Art. Lendings slightly decreased in years 2012 and 2013. Of the three museums, only the Louvre

39 This exhibition also circulated in the National Gallery of Art in Canberra between 2009 and 2010 and in the Fine Arts Museum of San Francisco between 2010 and 2011.
Museum lent a turnkey exhibition in 2012 and in 2013. Since the programming of exhibitions depends on specific plans and the relations between museums as well as questions of time and space, inferring the cause of this decrease is difficult. But note that a massive earthquake struck northern Japan on March 11, 2011. ${ }^{40}$ Also keep in mind that the turnkey exhibition from the Louvre Museum in 2012 (the year after this earthquake), as is the form of the turnkey exhibition but an exhibition called Rencontre was organized to support the devastated areas and populations. For this exhibition, the Louvre Museum gathered 24 works and showed them at museums in Morioka, Sendai, and Fukushima. ${ }^{41}$

Figure 1 points out that Japan has annually hosted turnkey exhibitions by French museums over the last decade, suggesting that the country is one of the main destinations for turnkey exhibitions organized by French museums. Japan or Japanese museums welcome those organized not only by French museums but also by museums from all over the world for three main reasons. First, the Japanese public appreciates Western art. Second, some museums in Japan don' t have their own collections, including

40 An exhibition of surrealism organized by MNAM-CCI that was shown at the National Art Center in Tokyo on February 8, 2011 was disrupted for ten days, but after it reopened, this exhibition scored a strong frequentation. Refer to Centre Pompidou. Les bilans d'activité 2011, p. 123.

41 Rapport d'activité 2012 - Musée du Louvre [online]. p. 94, 98 [cit. 2017-8-24]. Available from www: < http://www.louvre.fr/sites/default/ files/medias/medias_fichiers/fichiers/pdf/louvrerapport-activites-2012.pdf > 
the National Art Center in Tokyo, which since its inauguration in 2007, has hosted many turnkey exhibitions organized by museums from around the world. Finally, Japan has a specific exhibition system, that is the exhibition sponsored by major newspapers which permit to carry out this type of operation paying the huge loan fees. All of the turnkey exhibitions presented in Japan are sponsored by major newspapers. This exhibition system allows hugely expensive turnkey exhibitions to be shown in Japan, subsidized by a newspaper company. For example, an exhibition entitled Paris du monde entier: artistes étrangers à Paris 1900-2005, organized by MNAM-CCI in 2007, was produced at a cost of 750000 euros. ${ }^{42}$ This turnkey exhibition was sponsored by the Asahi newspaper company; an exhibition called L'art de Monet et sa postérité, which was organized by the D'Orsay Museum in 2007, cost 500000 euros $^{43}$ and was sponsored by the Yomiuri newspaper company.

\subsection{Construction of public} authorities: tendencies for thematic turnkey exhibitions in Japan

I trace the thematic tendencies of the turnkey exhibitions of French museums in Japan. When we see the themes of the turnkey exhibitions organized by three French museums (the Louvre Museum, the D'Orsay Museum and MNAM-CCI) over the last decade, the themes are divided into three categories: a collection's highlights, one-person exhibitions, and exhibitions that focus on specific subjects.

\footnotetext{
42 MESMER, Philippe. Le Japon, nouvel eldorado pour les musées français. Le Monde, le 15 mai 2007.

43 Ibidem.
}

The exhibitions in the first category show the masterpieces of a museums, such as an exhibition entitled Post-impressionnisme, chefs-d'ouvre du musée d'Orsay was presented at the National Art Centre (Tokyo) in 2010 and an exhibition called Masterpieces from the Centre Pompidou, 1906-1977 was shown at the Tokyo Metropolitan Art Museum in 2016. These exhibitions showcase the most representative works of art from a particular collection and give a non-western audience a knowledge of Western art history. The turnkey exhibitions started from this premise.

The exhibitions in the second category focus on a particular artist and his or her art and also often show the work of other artists who have a connection, such as an exhibition entitled Corot et son époque, organized by the Louvre Museum, that circulated in the National Museum of Western Art (Tokyo) and in the Kobe City Museum in 2008, and an exhibition called Renoir. Chefs-d'ouvre des collections des musées d'Orsay et de l'Orangerie, presented at the National Art Center (Tokyo) in 2016. These monographic exhibitions, in other words, oneperson shows, are cost-effective due to the artist's reputation.

The exhibitions in the last category attempt to show the more advanced exhibitions, such as an exhibition entitled Paris du monde entier: artistes étrangers à Paris 1900-2005, organized by MNAMCCI and presented at the National Art Centre (Tokyo) in 2007. This exhibition not only featured Picasso, Brancusi, Modigliani, Chagall and Giacometti but also such relatively obscure artists as Simon Hantaï, Jean Tinguely, Matta, and Thomas Hirschhorn. We can see that Japanese public is becoming increasingly interested in more specialized subjects and anticipated exhibitions that provided new knowledge of Western art.

The popularity of turnkey exhibitions in Japan suggests that exhibitions are events that offer knowledge of Western art history to a non-western public. The success of such turnkey exhibitions reflects the fact that they are revenue sources for museums. Indeed, turnkey exhibitions are in great demand from countries with adequate financial resources, such as Japan.

\subsection{Formation of public taste: Japanese public's taste on Impressionism}

Cultural diffusion from museums due to the circulation of exhibitions creates an image of museums, even images of Western art during the reception process and promotes acculturation. In this section, I analyze the most frequently visited exhibitions over the last decade as part of the turnkey exhibitions of three French museums (the Louvre Museum, the D'Orsay Museum and MNAM-CCI).

Figure 2 shows the most visited turnkey exhibitions among thirty exhibitions organized by these three French museums from 2007 to $2016 .{ }^{44}$ The result is that the first places of this rank are occupied by the exhibitions on Impressionism, except an exhibition entitled Les Révolutions de l'âge classique. La peinture européenne du XVII siècle, organized by the Louvre Museum in $2009 .{ }^{45}$ As shown in the figure 2 , from second to fifth places in this rank are occupied by the exhibitions on Impressionism.

44 I counted the number of visitors to each museum. If the exhibition circulated in several places, I did not count the total number of visitors. 45 This exhibition circulated in the Kyoto Municipal Museum of Art during the period from July 30 to September 27, 2009 and attracted 618321 visitors. 


\begin{tabular}{|c|c|l|l|l|l|}
\hline Rank & Number of visitors & \multicolumn{1}{|c|}{ Exhibition's name } & \multicolumn{1}{|c|}{ Period } & \multicolumn{1}{|c|}{ Lender } & \multicolumn{1}{|c|}{ Borrower } \\
\hline 1 & 851256 & $\begin{array}{l}\text { Les Révolutions de lâge classique. } \\
\text { La peinture européenne du XVIle siècle }\end{array}$ & $2009 / 02 / 28-2009 / 06 / 14$ & Louvre & $\begin{array}{l}\text { National Museum of Western Art } \\
\text { (Tokyo) }\end{array}$ \\
\hline 2 & 777551 & $\begin{array}{l}\text { Post-impressionnisme, chefs-d’euvre du } \\
\text { musée d’Orsay }\end{array}$ & $2010 / 05 / 26-2010 / 08 / 16$ & Orsay & National Art Center (Tokyo) \\
\hline 3 & 704420 & Lart de Monet et sa postérité & $2007 / 04 / 07-2007 / 07 / 02$ & Orsay & National Art Center (Tokyo) \\
\hline 4 & 696442 & $\begin{array}{l}\text { Naissance de l'impressionnisme. } \\
\text { La liberté de peindre }\end{array}$ & $2014 / 07 / 09-2014 / 10 / 20$ & Orsay & National Art Center (Tokyo) \\
\hline 5 & 667897 & $\begin{array}{l}\text { Renoir. Chefs-d'œuvre des collections des } \\
\text { musées d'Orsay et de l'Orangerie }\end{array}$ & $2016 / 04 / 27-2016 / 08 / 22$ & Orsay & National Art Center (Tokyo) \\
\hline 6 & 662491 & $\begin{array}{l}\text { Musée du Louvre. Peinture de genre. } \\
\text { Scènes de la vie quotidienne }\end{array}$ & $2015 / 02 / 21-2015 / 06 / 01$ & Louvre & National Art Center (Tokyo) \\
\hline
\end{tabular}

Fig. 2: Rank of most visited turnkey exhibitions in Japan from 2007 to 2016 by volume in descending order

Attracting 777551 visitors, an exhibition called Postimpressionnisme, chefs-d'œuvre du musée d'Orsay (Rank 2) was shown at the National Art Center (Tokyo) in 2010. The D'Orsay Museum, to achieve this turnkey exhibition, lent 115 works of art from its collection. This exhibition shows the origins of Impressionism from the end of the 19th century to the beginning of the 20th century. Japanese public could see the works of art from such artists as Monet, Degas, Cézanne, Gogh, Gogain, and Seurat.

An exhibition entitled L'art de Monet et sa postérité (Rank 3) was presented at the National Art Center in 2007, the museum's first year, and was visited by 704420 people. 97 works of art were shown that had been mainly borrowed from the D'Orsay Museum. This exhibition focused on Monet's art and explained its influence on his posterity.

An exhibition called Naissance de l'impressionnisme. La liberté de peindre (Rank 4) was shown at the National Art Center in 2014. Planning for 140 years since the first impressionist exhibition held in 1874, this exhibition was organized around 84 masterpieces from the collection of the D'Orsay Museum and received 696442 visitors. Without traveling to Paris, it provided the opportunity to experience some great works from collection of the D'Orsay Museum, such as Manet's Le fifre (1866), Caillebotte's Raboteurs de parquet (1875), and Cabanel's La naissance de Venus (1863).

An exhibition entitled Renoir. Chefs-d'ouvre des collections des musées d'Orsay et de l'Orangerie (Rank 5) was presented at the National Art Center in 2016. The D'Orsay Museum and the Orangerie Museum ${ }^{46}$ gathered over 100 works of art for this turnkey exhibition to illustrate Renoir's art throughout his whole life and received 667 897 visitors. Le Bal du Moulin de la galette, one of the masterpieces of the D'Orsay's collection, and Les baigneuses, a masterpiece of Renoir's later years, were presented in Japan for the first time.

To demonstrate the Japanese public's appreciation of Impressionism and the exhibitions organized by French museums, we compared the number of visitors to turnkey exhibitions organized by other museums.

\footnotetext{
46 Since June 1, 2010, the Orangerie Museum is attached to the D'Orsay Museum considered to be one single public institution of an administrative nature. JORF n'301 du 30 décembre 2003 page 22464 texte $n^{\circ} 74$. Décret $n^{\circ} 2003-1300$ du 26 décem bre 2003 portant création de l'Etablissement public du musée d'Orsay et du musée de l'Orangerie. NOR: MCCB0300911D [online]. [cit. 2017-11-14]. Available from www: <https://www.legifrance. gouv.fr/affichTexte.do?cidTexte=JORFTEXT000000611798\&categorieLien $=\mathrm{id}>$.
}

An exhibition called The Body Beautiful in Ancient Greece from the British Museum was presented at the National Museum of Western Art (Tokyo) in 2011 and received 257400 visitors. An exhibition entitled Goya: Lights and Shadow. Masterpieces of the Museo del Prado was presented at the National Museum of Western Art from 2011 to 2012 and got 333910 visitors. An exhibition called 400 Years of European Masterpieces from the State Hermitage Museum was presented at the National Art Center in 2012 and received 392949 visitors. An exhibition called Earth, Sea, and Sky: Nature in Western Art; Masterpieces from The Metropolitan Museum of Art was shown at the Tokyo Metropolitan Art Museum from 2012 to 2013 and received 328770 visitors. Featuring works from Impressionism to Surrealism, an exhibition entitled Masterpieces from the Kunsthaus Zürich was shown at the National Art Center in 2014 and marked 300086 visitors. ${ }^{47}$

We understand that the circulation of works of art and exhibitions,

\footnotetext{
47 Note the following exception. An exhibition entitled Masterpieces from the Royal Picture Gallery Mauritshuis was presented at the Tokyo Metropolitan Art Museum in 2012 and received 758 266 visitors. This result reflects that this museum reopened in this year after the restoration and its exhibition rooms were completely renovated, and Vermeer's Girl with a Pearl Earring attracted broad public support.
} 
especially turnkey exhibitions which expose a collection to wider audiences, builds the images of museum, forges branding strategies, and adds to the reputations of museums. Indeed, such turnkey exhibitions organized by three French museums (the Louvre Museum, the D'Orsay Museum, and MNAM-CCI) attracted the attention of Japanese art-lovers and set attendance records.

The exhibitions ranked from second to fifth were well planned to generate public interest. As noted in Chapter 1, since Japan has historically hosted exhibitions organized by French museums, French art is familiar to Japanese audiences who have gained knowledge of Western art through such exhibitions and want to learn more. These exhibitions offer to the public more specialized subjects: not only highlights of collections or one-person shows but also stories and background context that provide advanced knowledge of Western art.

\section{Conclusion}

I focused on the circulation of works of art and exhibitions and their effects. The circulation of works of art related to temporary exhibitions intensified from the early 20th century. Such circulation suggests not just a material displacement but also a symbolic displacement. This movement determines the taste of the public, the construction of a museum's reputation, and the phenomenon of acculturation.

The circulation of works of art and exhibitions fuels acculturation, as in the case of Japan. As this work clarified, Japan has historically hosted temporary exhibitions of French museums and turnkey exhibitions of worldwide museums. Focusing on its relationship with the Louvre Museum, the D'Orsay Museum, and MNAM-CCI, Japan is an important partner with these three museums because it is the main destination for their turnkey exhibitions. The Japanese public gained knowledge of Western art and were exposed to new ideas and concepts of art. They became familiar with Western art and the knowledge it advances through increasingly popular thematic exhibitions in Japan. This process shows acculturation with regards to the circulation of works of art and exhibitions.

In addition, from a cultural point of view, the movement of works of art and exhibitions stimulates interest in museum collections and provides a great value to them. The museums also reap financial benefits through loan fees. Thus, the circulation of works of art and exhibitions is one strategy of museums to grow international culture in a dynamic perspective that promotes the acculturation process.

\section{BIBLIOGRAPHY:}

Archives des musées nationaux, 4CC49 Prêt de la Vénus de Milo.

Asahi Shimbun, 1961, December 4.

Documentation AGER, Ma0399 Vénus de Milo.

Cat.Expo. Exposition d'art Français contemporain. Tokyo, Nichifutsu Geijutsusha, 1929. Catalogue.

Cat.Expo. Exposition d'art français contemporain; œuvres présentées à Paris au Salon de Mai 1950. Tokyo: Mainichi Shimbun, 1951. Catalogue.

Cat.Expo. Exposition d'art Français au Japon. Tokyo: Asahi Shimbun, 1954. Catalogue.

Centre Pompidou. Les bilans d'activité 2009-2016 [online]. [cit. 2017-8-24]. Available from www: < https://www. centrepompidou.fr/fr/Le-CentrePompidou/Les-bilans-d-activite $>$. Centre Pompidou. Les bilans d'activité 2011.
CHATELAIN, Jean. Droit et administration des musées. Paris: La Documentation française, 1993.

HASKELL, Francis. The Ephemeral Museum: Old Master Paintings and the Rise of the Art Exhibition. New Haven, London: Yale University Press, 2000. ISBN 978-0-300-08534-1.

JEANNERET, Yves. Penser la trivialité. Paris: Lavoisier, 2008. ISBN 978-2-7462-1878$-9$.

JORF n 301 du 30 décembre 2003 page 22464 texte $n^{\circ} 74$. Décret $n^{\circ} 2003-1300$ du 26 décembre 2003 portant création de l'Etablissement public du musée d'Orsay et du musée de l'Orangerie. NOR: MССВ0300911D [online]. [cit. 2017-11-14]. Available from www: < https://www.legifrance.gouv.fr/ affichTexte.do?cidTexte $=$ JORFTEXT000000611798\&categorieLien $=\mathrm{id}>$.

LATOUR, Bruno. Ces réseaux que la raison ignore: laboratoires, bibliothèque, collections. In BARATIN, Marc and Christina JACOB (eds.). Le pouvoir des bibliothèques: La mémoire des livres en Occident. Paris: Albin Michel, 1996. ISBN 978-2-226-07901-5.

MESMER, Philippe. Le Japon, nouvel eldorado pour les musées français. $L e$ Monde, le 15 mai 2007.

Musée D'Orsay. Rapport d'activité 2007-2016 [online]. [cit. 2017-8-24]. Available from www: <http://www.musee-orsay.fr/fr/ info/etablissement-public/rapportsdactivite.html >.

PALMER, Norman. Art Loans. London: Kluwer Law International and International Bar Association, 1997. ISBN 978-90-411-0667-4.

RAFFESTIN, Claude. Pour une géographie du pouvoir. Paris: Librairies Techniques, 1980. ISBN 978-2-7111-0271-6.

SPAAK, Isabelle. L'essor du clé en main. Le Journal des Arts, mars 1997, no. 34.

Rapport d'activité 2007 - Musée du Louvre [online]. [cit. 2017-8-24]. Available from www: <http://www.louvre.fr/sites/ default/files/medias/medias_fichiers/ fichiers/pdf/louvre-rapports-d039activite-2007.pdf $>$.

Rapport d'activité 2008 - Musée du Louvre [online]. [cit. 2017-8-24]. Available from www: <http://www.louvre.fr/sites/ default/files/medias/medias_fichiers/ 
fichiers/pdf/louvre-rapports-d039activite-2008.pdf $>$.

Rapport d'activité 2009 - Musée du Louvre [online]. [cit. 2017-8-24]. Available from www: <http://www.louvre.fr/sites/ default/files/medias/medias_fichiers/ fichiers/pdf/louvre-rapports-d039activite-2009.pdf $>$.

Rapport d'activité 2010 - Musée du Louvre [online]. [cit. 2017-8-24]. Available from www: <http://www.louvre.fr/sites/ default/files/medias/medias_fichiers/ fichiers/pdf/louvre-rapports-d039activite-2010.pdf $>$.

Rapport d'activité 2011 - Musée du Louvre [online]. [cit. 2017-8-24]. Available from www: <http://www.louvre.fr/sites/ default/files/medias/medias_fichiers/ fichiers/pdf/louvre-rapport-d039activites-2011.pdf $>$.

Rapport d'activité 2012 - Musée du Louvre [online]. [cit. 2017-8-24]. Available from www: <http://www.louvre.fr/sites/default/files/medias/medias_fichiers/fichiers/pdf/louvre-rapport-activites-2012. pdf $>$.

Rapport d'activité 2013 - Musée du Louvre [online]. [cit. 2017-8-24]. Available from www: <http://www.louvre.fr/sites/default/files/rapport_activite/fichiers/pdf/ louvre-rapport-d-activites-2013.pdf $>$.

Rapport d'activité 2014 - Musée du Louvre [online]. [cit. 2017-8-24]. Available from www: <http://www.louvre.fr/sites/default/files/medias/medias_fichiers/fichiers/pdf/louvre-rapport-d-activites-2014. pdf $>$.

Rapport d'activité 2015 - Musée du Louvre [online]. [cit. 2017-8-24]. Available from www: <http://www.louvre.fr/sites/default/files/medias/medias_fichiers/fichiers/pdf/louvre-rapport-d-activite-2015. pdf $>$.

Rapport d'activité 2016 - Musée du Louvre [online]. [cit. 2017-8-24]. Available fromwww: < http://presse.louvre.fr/ rapport-dactivite-2016/>.

Rapport d'activité du Centre Pompidou 1997. The National Museum of Western Art [online]. [cit. 2017-8-24]. Available from www: <http://www.nmwa.go.jp/jp/ exhibitions/past/index.html>.

The National Art Center. NACT Report 20072014 [online]. [cit. 2017-8-24]. Available from www: <http://www.nact.jp/information/introduce/report/ $>$.
Tokyo Metroplitan Art Museum. Annual Report 2012 [online]. [cit. 2017-8-24]. Available from www: <http://www. tobikan.jp/media/pdf/h24/archives_report_h24.pdf >.

Tokyo Metroplitan Art Museum. Annual Report 2014 [online]. [cit. 2017-8-24]. Available from www: <http://www. tobikan.jp/media/pdf/h26/archives_report_h26.pdf $>$.

Tokyo Metroplitan Art Museum. Annual Report 2015 [online]. [cit. 2017-8-24]. Available from www: <http://www. tobikan.jp/media/pdf/h27/archives_report_h27.pdf $>$.

\section{HARUMI KINOSHITA}

Musashi University, Tokyo, Japan kinoshita.harumi@gmail.com

Harumi Kinoshita was born in Japan and received a Doctor's degree in the Science of Information and Communication from the University of Avignon (France) in 2011. Her areas of expertise include museology and art history, especially the international diffusion of culture. She has been working at several museums and on museum projects, especially a special catalogue in 2007 for the 30th anniversary of the Pompidou Center. She currently works at Musashi University (Tokyo) as a part-time lecturer.

Harumi Kinoshita pochází z Japonska. Doktorát v oboru Informační věda a komunikace získala v roce 2011 na Univerzitě v Avignonu (Francie). Specializuje se na muzeologii a dějiny umění, zejména na téma šíření kultury v mezinárodním kontextu.

Pracovala v několika muzeích a podílela se na muzejních projektech, především na speciálním katalogu k 30. výročí Pompidouova centra v Pařízi v roce 2007. V současnosti pracuje jako externí přednášející na Univerzitě Musashi v Tokiu. 